\title{
Evaluation of serum 14-3-3n protein and Sema3A levels in rheumatoid arthritis: diagnostic and prognostic value
}

\author{
Nivine Fathi Darwish ${ }^{1}$, Shymaa Ahmed Hablas ${ }^{1 *}$ (D), Nivin Naeem Baiomy ${ }^{2}$ and El Sayed Mohamed Hamid Rageh ${ }^{1}$
}

\begin{abstract}
Background: Serum 14-3-3n protein plays an important role in the pathogenesis of rheumatoid arthritis (RA) as it is a joint-derived proinflammatory mediator. Semaphorin3A (Sema3A) plays an immune regulatory and bone remodeling role in many autoimmune diseases. Their role in rheumatoid arthritis needs to be evaluated for diagnostic and prognostic prospective values.

Results: The serum level of protein 14-3-3n was significantly higher in patients with RA than those in healthy controls. Serum 14-3-3n has a significant positive correlation with RF and ACPA, but not with either DAS28, ESR, or CRP. Serum 14-3-3n levels were significantly correlated with radiographically assessed joint damage. Serum Sema3A levels were decreased in rheumatoid arthritis patients compared to controls. There were also negative correlations with disease duration and activity score (DAS28), ESR, CRP, and RF.

Conclusion: The discriminative ability of 14-3-3n was comparable to RF and ACPA enhancing its diagnostic capacity. Sema 3A might serve as a predictive marker for radiographic severity and could have a potential therapeutic role in RA.
\end{abstract}

Keywords: Rheumatoid arthritis, Serum14-3-3n protein, Serum Sema3A, Proinflammatory mediators

\section{Background}

Rheumatoid arthritis (RA) is chronic autoimmune disease with a huge diversity in clinical picture, progression, and treatment response [1].

RA still constitutes an important cause of morbidity and mortality despite the great progression in treatment options [2].

The presence of autoantibodies to immunoglobulin G (rheumatoid factor-RF) and citrullinated proteins (anticitrullinated protein antibodies-ACPAs) are characteristic to RA. However, they are absent in the sera of some patients [3].

An erosive joint damage can be detected in about $20 \%$ of early RA patients within 2 years and is also observed

\footnotetext{
* Correspondence: shhablas@gmail.com

${ }^{1}$ Physical Medicine, Rheumatology and Rehabilitation, Faculty of Medicine,

Tanta University, Tanta, Gharbia Governorate, Egypt

Full list of author information is available at the end of the article
}

even in patients with clinical remission [4]. The progression of joint damage is one of the most significant causes of morbidity in RA [5].

There is a great need for more diagnostic and prognostic markers that can diagnose the disease early and reflect the prognosis of the disease especially its erosive nature [6].

The 14-3-3 family of intracellular chaperone proteins consists of seven isoforms: alpha/beta $(\alpha / \beta)$, epsilon $(\varepsilon)$, gamma $(\gamma)$, eta $(\eta)$, tau $(\tau)$, zeta $(\zeta)$, and sigma $(\sigma)[7]$. These proteins interact with more than 200 intracellular proteins to play a role in protein synthesis, cell cycle regulation, control of metabolism, protein trafficking, apoptosis, control of gene transcription, and cytoskeletal transport [8]. Serum 14-3-3 $\eta$ level increases in patients with arthritis as it can induce proinflammatory cytokines, like interleukin $1 \beta$ (IL-1 $\beta$ ), tumor necrosis factor$\alpha$ (TNF- $\alpha)$, and IL-6, and other factors leading to a joint

\section{Springer Open}

(อ) The Author(s). 2020 Open Access This article is licensed under a Creative Commons Attribution 4.0 International License, which permits use, sharing, adaptation, distribution and reproduction in any medium or format, as long as you give appropriate credit to the original author(s) and the source, provide a link to the Creative Commons licence, and indicate if changes were made. The images or other third party material in this article are included in the article's Creative Commons licence, unless indicated otherwise in a credit line to the material. If material is not included in the article's Creative Commons licence and your intended use is not permitted by statutory regulation or exceeds the permitted use, you will need to obtain permission directly from the copyright holder. To view a copy of this licence, visit http://creativecommons.org/licenses/by/4.0/. 
degradation including matrix metalloproteinase 9 and receptor activator of nuclear factor- $\mathrm{kB}$ ligand (RANKL) $[7,9]$.

Semaphorins are a large family of proteins containing a Sema domain of $\sim 500$ amino acids and that function as regulatory signals for axonal/dendritic projections have been initially known as neural guidance molecules [10].

They are categorized into 7 classes, semaphorins 1 to 7 [11]. They are implicated in different biological activities like angiogenesis, immune cell responses, and regulation of tumor microenvironment. Sema3A is a member of this family which contributes in the development and regulation of nervous system [12].

It has been involved in immune responses, organogenesis, angiogenesis, and oncogenesis [13]. Sema3A applies its osteoprotective role by inhibition osteoclast differentiation and stimulating osteoblastic bone formation at the same time synchronously [14].

Our objective is to study the role of these two new markers in rheumatoid arthritis.

\section{Methods}

This case-control study included 45 RA patients (group I) fulfilling the 2010 American College of Rheumatology/European League against Rheumatism classification criteria for RA [15].

They were recruited from the outpatient clinic of the Rheumatology Department from December 2018 to February 2020. The study also included 35 age- and sexmatched apparently healthy individuals as a control group (group II).

All patients were subjected to full medical history taking, complete clinical examination, evaluation of disease activity using Disease Activity Score 28 (DAS28), ESR, visual analog scale (range, $0-100$ ), and simplified disease activity index (SDAI) $[16,17]$.

\section{Inclusion criteria}

1- RA patients with disease duration less than 5 years.

\section{Exclusion criteria}

1- RA patients with other co-morbidities or chronic disease as diabetes mellitus or hypertension.

2- Patients who have received biological treatment.

\section{Laboratory investigations}

The laboratory investigations included the following: complete blood count, ESR, rheumatoid factor (RF), and C-reactive protein (CRP). Detection of serum anticycliccitrullinated peptide (anti-CCP) antibodies, liver function tests, and kidney function tests.
Serum 14-3-3 $\eta$ levels were evaluated by the quantitative 14-3-3 $\eta$ enzyme-linked immunosorbent assay (ELISA; Augurex Life Sciences Corp, Vancouver Canada) according to the manufacturer's protocol. Positivity for $14-3-3 \eta$ was defined by the manufacturer at $\geq$ $0.19 \mathrm{ng} / \mathrm{ml}$ Measurement of serum Sema3A level by $\mathrm{Hu}-$ man SEMA3A (Semaphorin 3A) ELISA Kit supplied by MyBioSource, San Diego, CA, USA; Catalog No: MBS2510626 with coefficient of variation is $<10 \%$ and detection range: $0.16-10 \mathrm{ng} / \mathrm{ml}$.

\section{Radiological investigations}

The radiological studies included the following:

(1) Plain X-ray scan on the hands and wrists (posteroanterior view) using the Modified Larsen Score (MLS) [18]

(2) Musculoskeletal ultrasonograghy using (SAMSUNG MEDISON (UGEO ${ }^{\mathrm{H} 60}$ ) machine with linear array transducers (frequencies ranging between 9 and $12 \mathrm{MHz}$ ) by certified MSUS operator blinded to the study. The joints were examined according to the EULAR and JCR guidelines at the radiocarpal, metacarpo-phalangeal joints, and proximal interphalangeal joints to detect a. Synovial thickening, effusion

b. Doppler flow by semiquantitative score [19].

\section{Statistical analysis}

Statistical presentation and analysis of the present study was conducted as continuous data and was expressed as mean \pm standard deviation or median. Comparison of continuous data between two groups was made by using Student's $t$ test and Mann-Whitney tests, and for categorical variables, chi-square test was used. Spearman correlation between different parameters was used. Statistical significance was defined as a $P$ value of $\leq 0.05$. The sensitivity, specificity, and accuracy were calculated by using receiver-operating characteristic analysis (ROC curve). Analyses were performed using SPSS program, version 17 (SPSS Inc., Chicago, IL, USA) and the GraphPad Prism software (GraphPad Prism Software Inc., San Diego, California, USA).

\section{Result}

The present study was conducted on 80 subjects. They were classified into two groups.

Group (I): rheumatoid arthritis patients $(n=45)$. Their ages ranged from 35 to 52 years with a mean age of $39.30 \pm 6.81$, mean disease duration of $41.6 \pm 6.7$ months, and mean DAS28 score of $8.5 \pm 12.2$. They were 37 females and 8 males.

Group (II): 35 healthy subjects age- and sex-matched served as a control group. Their ages ranged between 33 
and 51 years with a mean age of $40.70 \pm 4.0$. They were 29 females and 6 males.

The clinical and laboratory data of studied groups were illustrated in Table 1.

\section{Serum14-3-3n protein levels}

The serum levels of $14-3-3 \eta$ protein were significantly increased in RA patients compared to the control group $\left(P<0.001^{*}\right)$.

There were positive significant correlations with SDAI $\left(r=0.485, P=0.001^{*}\right)$, synovitis $\left(r=0.665, P<0.001^{*}\right)$, erosions $\left(r=0.864, P<0.001^{*}\right), \operatorname{RF}(r=0.374, P=$ $\left.0.011^{*}\right)$, and ACPA $(r=0.474, P=0.001)$. There were no correlations with ESR, CRP, or DAS28 score.

For diagnosis of RA, ROC curve showed that serum $14-3-3 \eta$ protein at a cutoff value of greater than $0.24 \mathrm{ng} / \mathrm{ml}$ had a sensitivity of $88.89 \%$, a specificity of $91.43 \%$, a positive predictive value of $93 \%$, and a negative predictive value of $86 \%$, and AUC was 0.957 (Tables 2, 3 , and 4; Fig. 1).

\section{Serum Sema3A level}

The serum levels Sema3A levels were significantly decreased in RA patients compared to the control group ( $P$ $\left.<0.001^{*}\right)$.

There were negative correlations with duration of the disease $\left(r=-0.372, P=0.012^{*}\right)$, disease activity (DAS28 score) $\left(r=-0.703, P<0.001^{*}\right)$, and simplified disease activity index (SDAI) $\left(r=-0.581, P<0.001^{*}\right)$, synovitis $(\mathrm{GSN})\left(r=0.501, P<0.001^{*}\right)$, and erosions $(r=0.652, P$ $\left.<0.001^{*}\right)$. ESR $\left(r=-0.535, P<0.001^{*}\right)$, RF $r=-0.645$, $\left.P<0.001^{*}\right)$, (CRP $\left.r=-0.668, P<0.001^{*}\right)$, and ACPA $(r$ $\left.=-0.787, P<0.001^{*}\right)$.

For diagnosis of RA, ROC curve showed that serum Sema3A at a cutoff value of lesser than or equal to 5.8 $\mathrm{ng} / \mathrm{ml}$ had a sensitivity of $82.82 \%$, a specificity of $80 \%$, a positive predictive value of $84.1 \%$, and a negative predictive value of $77.8 \%$, and AUC (area under the curve) was 0.854 (Tables 2, 3, and 4; Fig. 1).

\section{Discussion}

The need of new diagnostic markers for RA is crucial in particular subsets of rheumatoid arthritis patients such as those having an undifferentiated form of arthritis or those who progressively develop severe erosive disease.

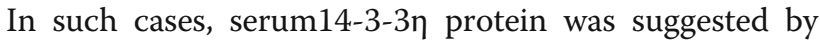
some authors as a novel detected biomarker for RA that has a diagnostic and prognostic value and the need for studies confirming this potential diagnostic and prognostic role seemed urgent $[7,20-24]$.

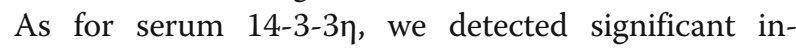
creased levels in our patients in comparison to controls with specificity value of $91.43 \%$ in comparison to $88.57 \%$ for ACCP, and also there were positive correlations with RF factor, ACPA. However, there were no correlations with DAS28, ESR, or CRP (Tables 1 and 2). In addition, there was a positive correlation between increased serum 14-3-3 $\eta$ levels and radiological changes (Table 3).

Our results strongly suggest the pathogenic and diag-

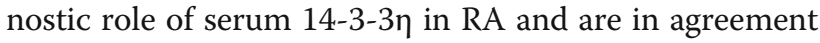
with Van Beers-Tas et al. (2016) who found serum14-3$3 \eta$ in the pre-clinical phase of arthritis and detected association between the positivity of this marker and ACPA- and/or RF-positive subjects with arthritis, compared with subjects with no arthritis. This can be explained by the ability of $14-3-3 \eta$ protein to provoke inflammatory and degenerative factors [7, 20, 25].

Carrier et al. (2016) observed in their study the same increase in $14-3-3 \eta$ protein in serum and synovial fluid of RA patients. Also, the association of production of inflammatory mediators like tumor necrosis factor $\alpha$ (TNF $\alpha)$, osteoclast-activating factors, and interleukin 6 (IL-6) in the patients' group [23]. Also, the persistent increase of $14-3-3 \eta$ protein level despite treatment could point out to patients at high risk of joint damage. The association between increased CRP and $14-3-3 \eta$ protein levels was considered by them as a bad prognostic indicator particularly in older individuals [23].

We found a positive correlation between increased

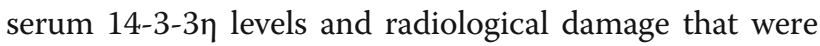

Table 1 Comparison between the two studied groups according to different clinical and laboratory parameters

\begin{tabular}{|c|c|c|c|c|}
\hline & $\begin{array}{l}\text { Patient group } \\
N=45\end{array}$ & $\begin{array}{l}\text { Control group } \\
N=35\end{array}$ & Test of significance & $p$ \\
\hline ESR 1st h $(\mathrm{mm} / \mathrm{h})$ & $34.1 \pm 16.9$ & $4.7 \pm 1.32$ & 10.25 & $<0.001^{*}$ \\
\hline RF( IU) median (min-max & $50(0-150)$ & $5(2-9)$ & $U=205.5^{*}$ & $<0.001^{*}$ \\
\hline CRP (mg/dl) median (min-max) & $60(2-96)$ & $1.0(0.0-2.0)$ & $U=6.5$ & $<0.001^{*}$ \\
\hline $\begin{array}{l}\text { ACCP }(\mathbf{U} / \mathbf{m l}) \\
\text { Median (min-max }\end{array}$ & $70(10-220)$ & $17(10-27)$ & $U=228.5^{*}$ & $<0.001^{*}$ \\
\hline $\begin{array}{l}\text { Serum 14-3-3 } \eta(\mathrm{ng} / \mathrm{ml}) \\
\text { Median (min-max }\end{array}$ & $0.45(0.14-0.69)$ & $0.14(0.07-0.34)$ & $U=68.5^{*}$ & $<0.001^{*}$ \\
\hline $\begin{array}{l}\text { Serum Sema3A }(\mathrm{ng} / \mathrm{ml}) \\
\text { Median (min-max }\end{array}$ & $3.9(1.8-6.1)$ & $6.5(2.1-8)$ & $U=1345.0^{*}$ & $<0.001^{*}$ \\
\hline
\end{tabular}

U Mann-Whitney test 
Table 2 Agreement (sensitivity, specificity) for different parameters to predict cases (vs control)

\begin{tabular}{lllllllll}
\hline & AUC & $\boldsymbol{p}$ & $\mathbf{9 5 \%}$ C.I & Cut off & Sensitivity & Specificity & PPV & NPV \\
\hline RF & 0.870 & $<0.001^{*}$ & $0.778-0.961$ & $>\mathbf{7}$ & 80.0 & 85.71 & 87.8 & 76.9 \\
ACCP & 0.855 & $<0.001^{*}$ & $0.764-0.946$ & $>\mathbf{2 2}$ & 84.44 & 88.57 & 90.5 & 81.6 \\
$\mathbf{1 4 - 3 - 3 ~} \eta$ & 0.957 & $<0.001^{*}$ & $0.916-0.997$ & $>\mathbf{0 . 2 4}$ & 88.89 & 91.43 & 93.0 \\
Sema3A & 0.854 & $<0.001^{*}$ & $0.755-0.953$ & $\leq \mathbf{5 . 8}$ & 82.82 & 80.0 & 86.5 \\
\hline
\end{tabular}

AUC Area under a curve, $p$ value probability value, $C I$ Confidence intervals, NPV Negative predictive value, PPV Positive predictive value

*Statistically significant at $p \leq 0.05$

detected by both X-ray and musculoskeletal U/S (Tables 3 and 4). This can be due to14-3-3n protein which activates several proinflammatory signaling cascades involved in the pathogenesis of RA. It also stimulates matrix metalloproteinase which participate in the joint damage cascade [7, 10].

We demonstrated the relation between disease activity score DAS28 results, gray scale synovitis assessment, and Doppler flow signal to both serum $14-3-3 \eta$ and Sema3A in (Table 4 and Fig. $2 \mathrm{a}-\mathrm{d}$ ).

Maksymowych et al. (2014) reported the same increase in serum 14-3-3n level in both early and established rheumatoid which was explained by the stimulation of extracellular regulated kinase 1,2 that leads to more joint damage through the production of interleukin 1 (IL-1), IL-6, receptor activator of nuclear factor $\mathrm{kB}$ ligand, and matrix metalloproteinase 1 [7].

Maksymowych et al. found that 14-3-3n correlated significantly with rheumatoid factor (RF) and anticitrullinated protein antibodies (ACPA) in RA, but not with $\mathrm{C}$ reactive protein (CRP) or the Disease Activity Score in 28 joints. The levels were higher in patients with more joint damage and can be used as a marker for radiographic progression and probably a new therapeutic target [7].

In this study, the discriminative ability of serum14-3$3 \eta$ is comparable to RF and ACPA, enhancing its diagnostic capacity (Table 2 ).

This agreed with El-Sherif et al. (2019) who observed

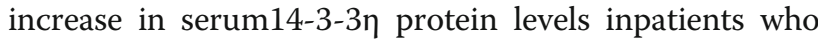
were seronegative for RF and ACPA which could enhance the sensitivity of RA diagnosis [26].

Guan et al. (2019) also found that the detection rate of RA patients can be improved using serum14-3-3 $\eta$ protein.

Zeng and Tan (2018) stated that the diagnostic capture of RA patients improved through combining serum14-3$3 \eta$ protein with rheumatoid factor and anticycliccitrullinated peptide antibody [27].

Sema3A has a role in autoimmune diseases through regulating lymphocytic function and an osteoprotective effect by stimulation of phospholipase C PLCY or suppression of RhoA signaling [28]. When its expression levels are distorted, it becomes responsible for abolishing the functions of regulatory $\mathrm{T}$ cells and allowing the infiltration and focal aggregation of autoreactive

Table 3 Correlation between the two markers and different parameters in patients group $(n=45)$

\begin{tabular}{|c|c|c|c|c|}
\hline & \multicolumn{2}{|c|}{ Serum $14-3-3 n$} & \multicolumn{2}{|c|}{ Serum Sema3A } \\
\hline & $r_{s}$ & $p$ & $r_{s}$ & $p$ \\
\hline Age (years) & -0.040 & 0.792 & 0.103 & 0.500 \\
\hline Duration of the disease (months) & 0.184 & 0.227 & $-0.372^{*}$ & $0.012^{*}$ \\
\hline DAS 28 & 0.358 & 0.06 & $-0.703^{*}$ & $<0.001^{*}$ \\
\hline ESR & 0.237 & 0.117 & $-0.535^{*}$ & $<0.001^{*}$ \\
\hline ACPA & $0.474^{*}$ & $0.001^{*}$ & $-0.787^{*}$ & $<0.001^{*}$ \\
\hline RF & $0.374^{*}$ & $0.011^{*}$ & $-0.645^{*}$ & $<0.001^{*}$ \\
\hline CRP & 0.307 & 0.065 & $-0.668^{*}$ & $<0.001^{*}$ \\
\hline SDAI & $0.485^{*}$ & $0.001^{*}$ & $-0.581^{*}$ & $<0.001^{*}$ \\
\hline SYNOVITIS & $0.665^{*}$ & $<0.001^{*}$ & $-0.501^{*}$ & $<0.001^{*}$ \\
\hline Erosions & $0.864^{*}$ & $<0.001^{*}$ & $-0.652^{*}$ & $<0.001^{*}$ \\
\hline
\end{tabular}

Serum 14-3-3n protein levels: There were positive significant correlations with SDAI $(r=0.485, P=0.001 *)$, SYNOVITIS $(r=0.665, P<0.001 *)$, degree of erosion $(r=$ $\left.0.864, P<0.001^{*}\right)$, RF $\left(r=0.374, P=0.011^{*}\right)$, and ACPA $(r=0.474, P=0.001)$. There were no correlations with ESR, CRP, or DAS score. Serum Sema3A level: There were negative correlations with duration of the disease $\left(r=0.372, P=0.012^{*}\right)$, disease activity (DAS28 score) $\left(r=-0.703, P<0.001^{*}\right)$, SDAI $(r=-0.581, P<0.001 *)$, GSN scale $\left(r=0.501, P<0.001^{*}\right)$, and degree of erosion $\left(r=0.652, P<0.001^{*}\right)$. ESR $\left.\left(r=-0.535, P<0.001^{*}\right), \operatorname{RF} r=0.645, P<0.001^{*}\right),\left(C R P r=-0.668, P<0.001^{*}\right)$, and ACPA $\left(r=-0.787, P<0.001^{*}\right)$ 


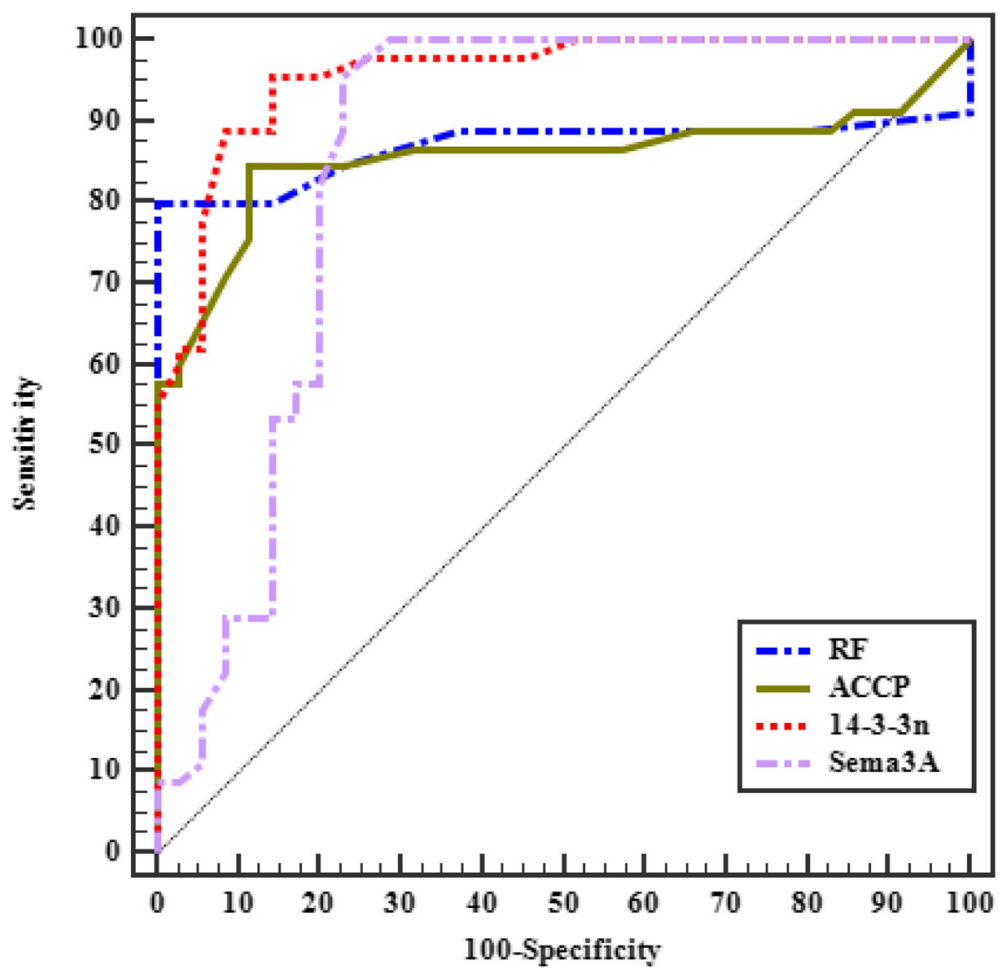

Fig. 1 ROC curve for different parameters to predict cases (vs control). Receiver-operating characteristic curve (ROC) analysis showing that serum Sema3A at a cutoff value of lesser than or equal to $5.8 \mathrm{ng} / \mathrm{ml}$ has a sensitivity of $82.82 \%$, a specificity of $80 \%$. AUC (area under the curve) is 0.854

lymphocytes in the synovial membrane. Subsequently, Sema3A levels in RA patients can be of an important significance $[11,28-30]$.

In this study, serum Sema3A levels were decreased in rheumatoid arthritis patients compared to controls. Also, there were also negative correlations with duration of the disease and disease activity score (DAS28), ESR, CRP, and RF (Tables 3 and 4).

Our results are compatible with Teng et al. (2017) who found a significant negative correlation between serum Sema3A levels and RF, CRP, and DAS28 in addition to lower levels of serum Sema3A detected in RA patients compared to osteoarthritis controls [31].

Sema3A also decreases the expression of many inflammatory cytokines secreted by peripheral blood mononuclear cell PBMCs. This role explains the negative correlations with disease duration and disease activity score (DAS28), ESR, and CRP [31].

Li et al. (2017) showed that Sema3A can be a hopeful biomarker for monitoring the RA activity as it is expressed in all skeletal lineages' cells and then secreted locally and in the blood flow [32].

Sema3A becomes an immunosuppressive regulator that can initiate an immune inhibitory response by making a complex with neuropilin-1 and plexin-A4 [33]. This action was proven in several studies through the induction of Sema3A expression in animal models with arthritis and reported reduced severity and damage of articular surface [34].

In contrast to our results, $\mathrm{Ha}$ et al. (2018) found higher serum levels of Sema3A in patients with RA than those in healthy controls and showed a negative

Table 4 Relation between DAS 28 with 14-3-3n and Sema3A in patients' group $(n=45)$

\begin{tabular}{|c|c|c|c|c|c|c|}
\hline & \multicolumn{4}{|l|}{ DAS 28} & \multirow[t]{2}{*}{$H$} & \multirow[t]{2}{*}{$p$} \\
\hline & $\begin{array}{l}\text { Clinical remission } \\
(<2.6)(n=7)\end{array}$ & $\begin{array}{l}\text { Low disease activity } \\
(2.6-3.2)(n=10)\end{array}$ & $\begin{array}{l}\text { Moderate disease activity } \\
(3.2-5.1)(n=5)\end{array}$ & $\begin{array}{l}\text { High disease activity } \\
(>5.1)(n=23)\end{array}$ & & \\
\hline \multicolumn{7}{|l|}{$14-3-3 n$} \\
\hline Median (Min.-Max.) & $0.28(0.25-0.47)$ & $0.25(0.14-0.60)$ & $0.55(0.26-0.67)$ & $0.59(0.16-0.69)$ & $17.928^{*}$ & $<0.001^{*}$ \\
\hline \multicolumn{7}{|l|}{ Sema3A } \\
\hline Median (Min.-Max.) & $5.5(3.8-5.8)$ & $5.9(5-6.1)$ & $4.1(2.6-6.1)$ & $2.9(1.8-4.7)$ & $28.918^{*}$ & $<0.001^{*}$ \\
\hline
\end{tabular}

$\mathrm{HH}$ for Kruskal Wallis test, $p p$ value for association between different categories

*Statistically significant at $p \leq 0.05$ 

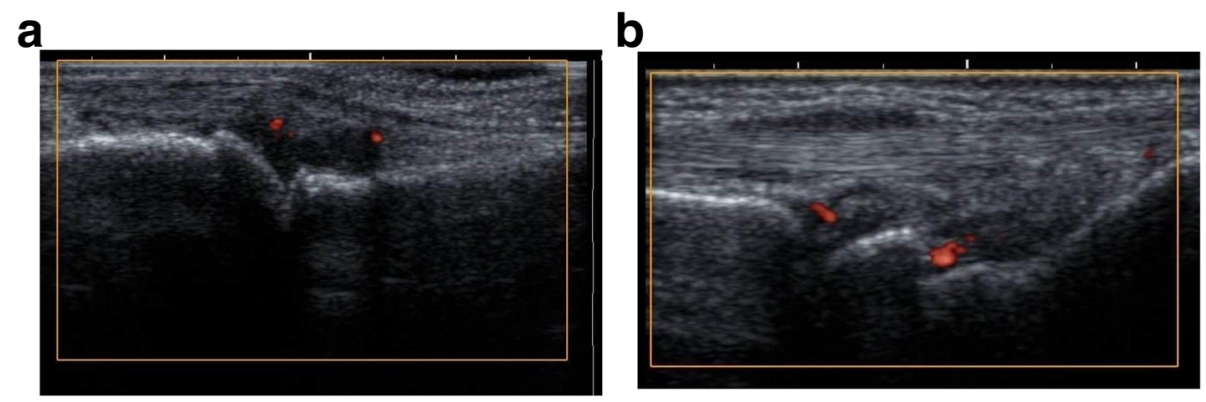

C

d
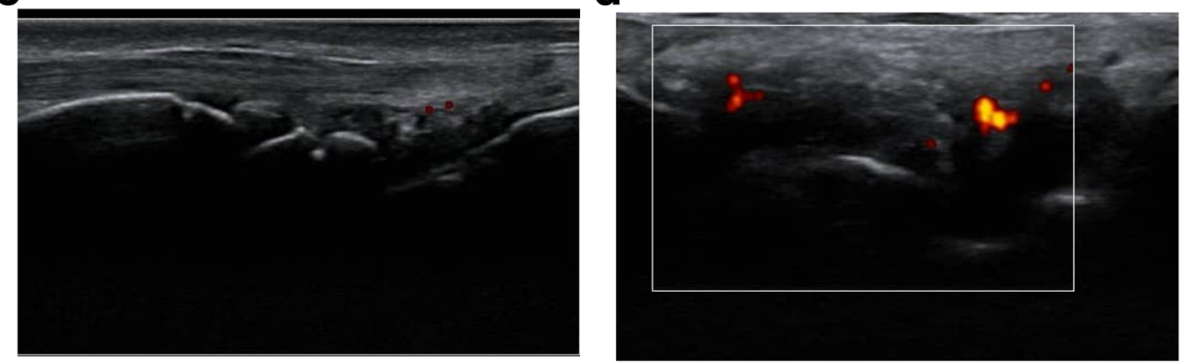

Fig. 2 Relation between the gray scale ultrasound scan and Doppler flow signal with Sema3A and 14-3-3n protein levels. a Longitudinal scan of the metacarpophalangeal joints showing synovitis grade 3 with Doppler signal grade1 (low-disease activity score). The 14-3-3n protein level showed an increase up to $0.49 \mathrm{ng} / \mathrm{ml}$ (controls $0.14 \mathrm{ng} / \mathrm{ml}$ ) and Sema3A level showed mild decrease $5.1 \mathrm{ng} / \mathrm{ml}$ (controls $6.5 \mathrm{ng} / \mathrm{ml}$ ). b Longitudinal scan of the radiocarpal and intercarpal joints showing synovitis grade 2 Doppler signal grade 1 (low-disease activity score). Serum 14-3-3nprotein level is $0.46 \mathrm{ng} / \mathrm{ml}$ and Sema3A level is $4.1 \mathrm{ng} / \mathrm{ml}$. c Longitudinal scan of the intercarpal joints showing erosion and grade 2 synovitis and grade 1 Doppler signal (low-disease activity score with erosions). The $14-3-3 \eta$ protein level is $0.5 \mathrm{ng} / \mathrm{ml}$, and Sema3A level is $5.9 \mathrm{ng} /$ $\mathrm{ml}$. d Longitudinal scan of the wrist showing grade 3 synovitis and grade 2 Doppler signal with effusion (moderate disease activity score). The 14$3-3 n$ protein level is $0.61 \mathrm{ng} / \mathrm{ml}$, and Sema3A level is $3.5 \mathrm{ng} / \mathrm{ml}$

correlation with Dkk-1 and tumor necrosis factor- $\alpha$ and found non-significant correlation with radiographic damage assessed using the modified Larson score [35]. Our explanation is that there might be longitudinal changes in the serum level during the disease course that we were not able to detect in our study. Also, the longer disease duration of their patient that reached 81 months might play a factor in enhancing the release of this marker.

Using the ROC curve analysis, our study revealed a higher discriminative ability of serum Sema3A compared to RF and ACPA which enhances its diagnostic capacity (Fig. 1).

According to Gao et al. (2018), serum Sema3A level was significantly higher in RA patients than healthy controls, and it's mRNA expression level was increased in RA patients' PBMC than controls. The serum Sema3A level was positively correlated with platelet counts, ESR, RF, IgM, Larson score, and bone mineral density (BMD) of the lumbar spine. It was also significantly increased in antiCCP-positive groups compared to negative groups [36].

These conflicting results might be due to different sample sizes and heterogeneous RA patients in individual studies.

Our results showed a significant negative correlation between Sema3A levels and ultrasound detected bony erosions (Table 3).
Teng et al. (2017) examined the effects of Sema3A on macrophages, fibroblasts, and osteoclasts which are the cells primarily involved in the pathogenesis of RA and revealed that Sema3A-supported IL-4 stimulated M2 macrophage polarization, while inhibited LPS/IFN- $\gamma$ stimulated M1 polarization. Sema3A prevents endothelial cell proliferation and migration, represses fibroblast function, delays osteoclastogenesis, and performs a protective role in RA. Teng et al. concluded that Sema3A administration diminishes joint tissue damage and the severity of experimental arthritis and offers promising preventive and therapeutic strategies in arthritis [31].

\section{Conclusion}

Measuring serum 14-3-3 $\eta$ protein and Sema3A levels seem to have higher discriminative diagnostic utility in RA. Addition of these markers to ordinary known tests might lead to better diagnosis and evaluation of RA. Sema3A offers a potential therapeutic role for further studies to confirm these promising results.

\section{Recommendations}

Future long-term studies are to follow-up patients and to study whether these markers could have a prognostic value. Also, the relation between these markers and the pathogenesis of RA needs to be investigated. 


\section{Abbreviations}

RA: Rheumatoid arthritis; RF: Rheumatoid factor; ACPAs: Anti-citrullinated protein antibodies; IL-1 $\beta$ : Interleukin 1 $\beta$; TNF-a: Tumor necrosis factor-a; DAS28: Disease Activity Score 28; ESR: Erythrocyte sedimentation rate; SDAI: Simplified Disease Activity Index; PBMCs: Peripheral blood mononuclear cells; ROC curve: Receiver-operating characteristic

\section{Acknowledgements}

Not applicable

\section{Authors' contributions}

NF set the design, collected the data, and performed the data analysis. SA collected the data and performed the analysis and drafting. NN performed the analysis and interpretation of the data and drafting. ER suggested the study design, performed the blind ultrasonograghic evaluation for all cases, and shared in the drafting. The authors read and approved the final manuscript.

\section{Funding}

We did not receive any funds for this study.

\section{Availability of data and materials}

The datasets used and/or analyzed during the current study are available from the corresponding author on reasonable request.

\section{Ethics approval and consent to participate}

The study was implemented in agreement with the ethical principles of Helsinki and was approved by the local Research Ethics Committee of Faculty of Medicine, Tanta University (approval code 31084/07/19). All of the participants gave written informed consent after a full explanation of the study.

\section{Consent for publication}

Not applicable

\section{Competing interests}

No competing interest to disclose.

\section{Author details}

${ }^{1}$ Physical Medicine, Rheumatology and Rehabilitation, Faculty of Medicine, Tanta University, Tanta, Gharbia Governorate, Egypt. ${ }^{2}$ Department of Clinical Pathology, Faculty of Medicine, Tanta University, Tanta, Egypt.

Received: 29 July 2020 Accepted: 19 October 2020

Published online: 11 December 2020

\section{References}

1. Bugatti S, Manzo A, Montecucco C, Caporali R (2018) The clinical value of autoantibodies in rheumatoid arthritis. Front Med (Lausanne) 5:339

2. Bykerk VP, Akhavan P, Hazlewood GS, Schieir O, Dooley A, Haraoui B et al (2012) Canadian rheumatology association recommendations for pharmacological management of rheumatoid arthritis with traditional and biologic disease modifying antirheumatic drugs. J Rheumatol 39:1559-1582

3. Smolen JS, Aletaha D, Barton A, Burmester GR, Emery P, Firestein GS, Kavanaugh A, Mclnnes IB, Solomon DH, Strand V et al (2018) Rheumatoid arthritis. Nat Rev Dis Primers 4:18001

4. Van der Kooij SM, Goekoop-Ruiterman YP, de Vries-Bouwstra JK, GülerYüksel M, Zwinderman AH, Kerstens PJ et al (2009) Drug-free remission, functioning and radiographic damage after 4 years of response-driven treatment in patients with recent-onset rheumatoid arthritis. Ann Rheum Dis 68(6):914-921

5. Scott DL, Pugner K, Kaarela K, Doyle DV, Woolf A, Holmes J et al (2000) The links between joint damage and disability in rheumatoid arthritis. Rheumatology (Oxford) 39(2):122-132

6. Rooy DP, van der Linden MP, Knevel R, Huizinga TW, van der Helm-van Mil $\mathrm{AH}$ (2011) Predicting arthritis outcomes-what can be learned from the Leiden early arthritis clinic? Rheumatology (Oxford) 50:93-100

7. Maksymowych WP, Van Der Heijde D, Allaart CF, Landewé R, Boire G, Tak PP et al (2014) 14-3-3eta is a novel mediator associated with the pathogenesis of rheumatoid arthritis and joint damage. Arthritis Res Ther 16:R99
8. Obsilová V, Silhan J, Boura E, Teisinger J, Obsil T (2008) 14-3-3 proteins: a family of versatile molecular regulators. Physiol Res 57(3):S11-S21

9. Van de Stadt LA, Witte BI, Bos WH, van Schaardenburg D (2013) A prediction rule for the development of arthritis in seropositive arthralgia patients. Ann Rheum Dis 72(12):1920-1926

10. Kolodkin AL, Matthes DJ, Goodman CS (1993) The semaphorin genes encode a family of transmembrane and secreted growth cone guidance molecules. Cell. 75(7):1389-1399

11. Nishide M, Kumanogoh A (2018) The role of semaphorins in immune responses and autoimmune rheumatic diseases. Nat Rev Rheumatol 14(1): 19-31

12. He Z, Wang KC, Koprivica V, Ming G, Song HJ. (2002) Knowing how to navigate: mechanisms of semaphorin signaling in the nervous system. Sci STKE. 2002;(119):re1. https://doi.org/10.1126/stke.2002.119.re1

13. Adams $\mathrm{RH}$, Eichmann A (2010) Axon guidance molecules in vascular patterning. Cold Spring HarbPerspect Biol 2(5):a001875

14. Hayashi M, Nakashima T, Taniguchi M, Kodama T, Kumanogoh A, Takayanagi H (2012) Osteoprotection by semaphorin 3A. Nature. 485:69-74

15. Aletaha D, Neogi T, Silman AJ, Funovits J, Felson DT, Bingham CO 3rd et al (2010) Rheumatoid arthritis classification criteria: an American College of Rheumatology/European league against rheumatism, collaborative initiative. Arthritis Rheum 62(9):2569-2581

16. Wells G, Becker JC, Teng J, Dougados M, Schiff M, Smolen J et al (2009) Validation of the 28-joint disease activity score (DAS28) and European league against rheumatism response criteria based on C-reactive protein against disease progression in patients with rheumatoid arthritis, and comparison with the DAS28 based on erythrocyte sedimentation rate. Ann Rheum Dis 68(6):954-960

17. Smolen JS, Breedveld FC, Schiff MH, Kalden JR, Emery P, Eberl G et al (2003) A simplified disease activity index for rheumatoid arthritis for use in clinical practice. Rheumatology (Oxford) 42(2):244-257

18. Larsen A (1995) How to apply Larsen score in evaluating radiographs of rheumatoid arthritis in long term studies? J Rheumatol 22:1974-1975

19. Terslev L, Naredo E, Aegerter P, Wakefield RJ, Backhaus M, Balint P et al (2017) Scoring ultrasound synovitis in rheumatoid arthritis: a EULAROMERACT ultrasound taskforce-part 2: reliability and application to multiple joints of a standardised consensus-based scoring system. RMD Open 3(1): e000427

20. Maksymowych WP, Naides SJ, Bykerk V, Siminovitchk KA, van Schaardenburg D, Boers $M$ et al (2014) Serum 14-3-3n is a novel marker that complements current serological measurements to enhance detection of patients with rheumatoid arthritis. J Rheumatol 41:210413

21. Mohamed AH, Abdellatif S, El-Noshokaty (2018) Serum level of 14-3-3n (eta) protein as a diagnostic marker for rheumatoid arthritis and potential correlation with disease activity. MOJ Orthop Rheumatol 7(4):00280

22. Van Schaardenburg D, Maksymowych WP, Boers M, Van Beers-Tas MH, Marotta A (2014) Serum 14-3-3n predicts the risk of RA development and its higher titres are associated with higher risk. Ann Rheum Dis 73(2):602

23. Carrier N, Marotta A, de Brum-Fernandes AJ, Liangs $P$, Masetto A, M enard HA (2016) Serum levels of 14-3-3n protein supplement C-reactive protein and rheumatoid arthritis-associated antibodies to predict clinical and radiographic outcomes in a prospective cohort of patients with recentonset inflammatory polyarthritis. Arthritis Res Ther 18:37

24. Kilani RT, Maksymowych WP, Aitken A, BoireG S-PY, Li Y, Ghahary A (2007) Detection of high levels of 2 specific isoforms of 14-3-3 proteins in synovial fluid from patients with joint inflammation. J Rheumatol 34: 1650-1657

25. Van Beers-Tas MH, Marotta A, Boers M, Maksymowych WP, Van Schaardenburg D (2016) A prospective cohort study of 14-3-3n in ACPA and/or RF-positive patients with arthralgia. Arthritis Res Ther 18:76

26. El-Sherif WT, Nigm DA, Abd-Elsamea MH, Kassem AM (2019) Evaluation of serum protein $14-3-3 \eta$ (eta) as a novel biomarker for rheumatoid arthritis. Egypt J Immunol 27(1):163-175

27. Zeng T, Tan L (2018) 14-3-3n protein: a promising biomarker for rheumatoid arthritis. Biomark Med 12(8):917-925

28. Verlinden L, Vanderschueren D, Verstuyf A (2016) Semaphorin signaling in bone. Mol Cell Endocrinol 432:66-74

29. Takagawa S, Nakamura F, Kumagai K, Nagashima Y, Goshima Y, Saito (2013) Decreased semaphorin3A expression correlates with disease activity and histological features of rheumatoid arthritis. BMC Musculoskelet Disord $14: 40$ 
30. Xu R (2014) Semaphorin 3A: a new player in bone remodeling. Cell AdhMigr 8(1):5-10

31. Teng Y, Yin Z, Li J, Li K, Li X, Zhang Y (2017) Adenovirus-mediated delivery of Sema3A alleviates rheumatoid arthritis in a serum-transfer induced mouse model. Oncotarget. 8(39):66270-66280

32. Li Z, Hao J, Duan X, Wu N, Zhou Z, Yang F, Li J, Zhao Z, Huang S (2017) The role of Semaphorin 3A in bone remodeling. Front Cell Neurosci 11:40

33. Glinka Y, Prud'homme GJ (2008) Neuropilin-1 is a receptor for transforming growth factor beta-1, activates its latent form, and promotes regulatory $T$ cell activity. J Leukoc Biol 84:302-310

34. Garcia S (2019) Role of Semaphorins in immunopathologies and rheumatic diseases. Int J Mol Sci 20(2):347

35. Ha YJ, Han DW, Kim JH, Chung SW, Kang EH, Song YW et al (2018) Circulating Semaphorin $4 \mathrm{D}$ as marker for predicting radiographic progression in patients with rheumatoid arthritis. Dis Markers 2318386. https://doi.org/10.1155/2018/2318386

36. Gao H, Ma XX, Guo Q, Zou YD, Zhong YC, Xie LF et al (2017) Expression and clinical significance of Semaphorin $3 \mathrm{~A}$ in serum and mononuclear cells in patients with systemic lupus erythematosus. Zhonghua Yi XueZaZhi 97(5): 370-374

\section{Publisher's Note}

Springer Nature remains neutral with regard to jurisdictional claims in published maps and institutional affiliations.

\section{Submit your manuscript to a SpringerOpen ${ }^{\odot}$ journal and benefit from:}

- Convenient online submission

- Rigorous peer review

- Open access: articles freely available online

High visibility within the field

- Retaining the copyright to your article

Submit your next manuscript at $\boldsymbol{\nabla}$ springeropen.com 